\title{
Revisiting the Marginal Locations of Muslim Women on Various Sites in India
}

Esita Sur ${ }^{+}$

Abstract

Dominant discourses on Muslim women have revolved around their marginal locations in community as well as in society. It has mainly been subjected to socio-economic and political structures and conditions as well. However, it is worth mentioning that marginality is not only a lived experience but it also has metaphoric dimensions. The state of marginality relates not only to the poor socio-economic status of Muslim women but the politics of representation of their identities like veiled, passive as well as meek victims in various discourses also constructs the core of their marginal location in the larger society. Therefore, the marginalisation of Muslim women seems to be visible in various discourses in India. Briefly, the paper will attempt to comprehend the undercurrents functioning behind the construction of the very concept of marginality and locate Muslim women in popular and academic discourses on marginality.

Key words: Metaphors, Representation, Discourse, Marginality, Muslim Women, India

\footnotetext{
${ }^{\dagger}$ Assistant Professor in Political Science at Scottish Church College, Kolkata, Emails: esita_sur@yahoo.com, esitasur@rediffmail.com 


\section{Introduction}

The question of marginality is far from a novel topic. Moreover, locating the question of Muslim women's ${ }^{1}$ marginality in the popular development discourse is not an easy task. The concept of marginality is multidimensional. The Webster dictionary defines 'marginal' pertaining to a margin situated on the border or edge. Marginality can also be defined in terms of social exclusion from a dominant social order and it forms an institutionalised system of material and symbolic exchange. However, marginality is best understood as state or series of situations between social exclusion and social integration (Lovell, 2004). Dominant discourses ${ }^{2}$ on Muslim women in India have attempted to define and locate their marginal location in terms of socioeconomic backwardness such as lack of education, poverty, lack of employment opportunities and their invisibility in the labour force, etc. The Sachar Committee Report (2006) has highlighted the varied dimensions of marginality of Muslim community (Sachar, 2006). Muslim women as the member of the minority community suffer from all the symptoms of backwardness. However, the popular discourses rarely stereotype Muslim women as 'less educated' or 'unemployed' rather concentrates

\footnotetext{
${ }^{1}$ Muslim women in India should not be considered as a homogenous entity. Differences in their experiences are shaped by their location in class, region and family as well. Educational attainment and employment opportunities or lack of it, are also important indicators to mould their experiences. Therefore, the issue of heterogeneity needs to be mentioned. However, for the theoretical requirement I am addressing the equality question of Muslim women by considering them as a unitary category.

${ }^{2}$ The category of discourse refers to historically specific systems of meaning which form the identities of subjects and objects. Meanings are always dependent upon a socially constructed system of rules and significant differences. The concept of discourse has also been extended to a wider range of social practices and phenomena. Michel Foucault has discussed about the ways discursive practices form the objects and subjects of discursive formations. Discourses are thus practices, which systematically form the objects, which we speak. It also raises questions about the historical construction of systems and the exclusion of human subjectivity and agency from the social world (Howarth, 2002).
}

more on their 'veiled', 'victim' or 'passive' images.

There is no denial of the established fact that the marginal location of Muslim women in the mainstream society has been integrally associated with overall socio-economic backwardness of the community and the policies of the derelict Indian state as well. However, in case of Muslim women, what needs to be argued is that the state of marginality not only constitutes the core of their lived experiences but the very state itself goes through a process of construction involving a wide range of factors and agents in power structures. It becomes possible by constructing a context with deliberation and purpose of creating one's identity. Therefore, the marginal location of Muslim women in our society can also be viewed in the politics of representation of identities and knowledge production. For example, in dominant discourses, metaphors ${ }^{3}$ like talaq, ${ }^{4}$ hijab and burqa $^{5}$ fatwa have played quite significant roles to stereotype their identities as 'passive' 'fragile', and so on. The politics of representation lies in the fact that it is not only Muslim women but women from other communities also lack access to education and employment and are subject to several challenges. Sarkar (2008) argues that Muslim women have already been established discursively as backward and hence incapable of progressive thinking.

\footnotetext{
${ }^{3} \mathrm{~A}$ metaphor is a figure of speech that describes a subject by asserting that it is, on some point of comparison, the same as another otherwise unrelated object. Metaphor is a type of analogy and is closely related to other rhetorical figures of speech that achieve their effects via association, comparison or resemblance.

${ }^{4}$ Triple talaq is a form of divorce, which can take place in one setting by pronouncing talaq for three times. This practice is a male monopoly. The holy Quran does not support this but it is a product of male-dominated society.

${ }^{5}$ Hijab and burqa are two different kinds of clothing that are available to Islamic women. A hijab or hejab actually refers to the rules of covering up. However, in the usual everyday context, the word is used to refer to a scarf, which covers the head. A burqa, on the other hand, is a loose outer garment that covers the whole body head-totoe.
} 
It is also true that Muslim women's subjugation cannot be understood without referring to the politics of intersectionality ${ }^{1}$ of gender, class and community identity. Rather than looking at sameness approach, it is better to recognise the politics of difference. It is also important to understand that Muslim women themselves do not constitute a homogenous group. Their lived experiences vary on grounds of class, educational attainment and regional location, etc. Muslim women like women from other communities, are under-represented in workforce as well as in politics and their educational attainment is also meagre. However, these issues are not solely responsible which attributes difference to their issues. Rather the prevalence of religious patriarchy as well as personal laws contributes largely to the issue of difference. It also shows that intersection of gender, class as well as community not only form their identity but also controls their embeddedness in social structures as well as in relations of power (Sur, 2013).

It is because of the fact that metaphors like talaq and burqa have been perceived in a negative sense, which signals the victimhood of Muslim women and reinforces their marginality in popular discourses. For example, observing purdah or burqa has closely been associated with cultural pressure but it may not always be oppressive in nature. The practice may be an expression of cultural identity and a choice too. In the same manner, the practice of triple talaq may be relevant for a particular section of the community but in reality, it stigmatises the entire community and projects the victimhood of Muslim women. The reference to the issue of declaring fatwas by religious leaders also portrays the community as conservative

\footnotetext{
${ }^{1}$ Intersectionality seemed ideally suited to the task of exploring how categories of class, community and gender are intertwined and mutually constitutive, giving centrality to questions like how community is 'gendered' and how gender is 'class and community-based', and how both are linked to the continuities and transformations of social structures and cultural discourses (Collins, 2000).
}

especially for women, but the presence of a microscopic liberal progressive section within the community and their voices has hardly received attention in dominant discourses. This sort of representation of identities and bodies of knowledge on Muslim women and the community labels them as marginal and reproduces their victimhood in several discourses. Therefore, this entire process has ignited an enquiry to what extent the marginality question of Muslim women has been constructed by these dominant social forces.

In this venture, rather than addressing the question of rights and gender justice, the essay will try to highlight the complexities inherent in the construction process of the marginality question of Muslim women in India. Hence, the argument of the essay is that gendered marginality not only results from socioeconomic and political policies and conditions, but it also exists in various discourses, representations and bodies of knowledge that are being constructed and generated about Muslim women in India. Therefore, the essay will try to locate various posts and discourses where the marginality questions of Muslim women have been constructed.

\section{Community and Marginalisation: On Politics of Representation}

Dominant discourses ${ }^{2}$ on Muslim community have represented them as homogenous community spelled with a capital C. It not only upholds the ideals of unity and common experience of marginality but has also generated stereotypes. For example, Hindu nationalists have always levelled the community as 'terrorists', 'anti-nationals', 'suspicious' and Muslim males are labelled as 'husbands of four wives' and many of these stereotyping are more political creations and as

\footnotetext{
${ }^{2}$ Dominant discourses also include discourse analysis. It incorporates a wide range of linguistic and non-linguistic material-speeches, reports, manifestos, historical events, interviews, policies, ideas, even organisations and institutions-as 'texts' or 'writings' that enable the subjects to experience the world of objects, words and practices.
} 
far away from the reality as possible (Shaban, 2012: 19). However, the overall impact of this on the Muslim community is grave. It affects their psyche and confidence to assert their rights (Shaban, 2012). This sort of representation overlooks the fact that Muslims are deeply divided on the lines of caste, class and gender. Even on ideological standpoints, community is divided. Moreover, this homogeneous representation seems to be problematic for Muslim women as well. On the one hand, the hegemonic representation of the community as 'backward' or 'conservative' tends to fix women's identity in larger society; on the other hand, it also overlooks internal conflicts on the women's question within the community. The conservative, progressive as well as fundamentalist groups within the community have conflicting standpoints on women's rights in Islam. In India, the yardstick of defining an Islamic group or school as conservative depends not only on their unwillingness to accept western values but also on their rigid stand to accept women's rights, already guaranteed within the Islamic framework. Moreover, fundamentalists are those who always dodge to change their standpoint on women's rights. Several schools like Jafari, Hanafi, Maliki, Safai'i, Hanbali support men's right to triple talaq (talaq in one sitting), and polygamy as these are embedded in religion. Conservative interpretations also justify wife beating and impose several restrictions on women in the name of religion. Moreover, their perceptions and interpretations on women's role in society are based on rigid demarcations between men and women. On the contrary, progressiveness of an Islamic group in India cannot be defined in terms of their inclination for western values; rather progressive groups uphold the genderjust nature of Islam, which gives them extra mileage to fight for women's rights. Progressives like late Ashgar Ali Engineer have always argued that women's rights are inherent in Islam but the patriarchal society has taken the rights away from women. Progressive groups have not only relentlessly challenged the conservative interpretations but also exhorted for reinterpretations of the Quranic verses. However, in reality, progressive voices hardly are represented in larger society because the progressive voices constitute a microscopic minority and they do not seem to be lucrative as vote banks for the Indian State. The conservative section of the community is more powerful in terms of its authority and the women question is mainly handled by the conservative sections within the community. It has also been argued that the discursive ${ }^{1}$ representation of Muslim women as backward, victimised and silenced, and eventually invisible has undergirded the construction of other identity categories, and the politics of representation is based on difference among women rather than identity as crucial for understanding gender oppression and marginality. It also highlights the ways in which gender and racially defined community and class ideologies worked simultaneously to deny even middle-class Muslim women the limited visibility (Sarkar, 2008). Zoya Hasan and Ritu Menon have pointed out that recent interventions on Muslim women in postcolonial India are caught up in misconceptions that usually leave Muslim women invisible. Two sets of misunderstandings seem to plague discussions of Muslim women: the tendency to see Muslims, particularly Muslim women, as a monolithic category; and the overwhelming importance attached to Islam, especially the Muslim personal law in defining Muslim women's status (Menon, 2004). The making of the category of Muslim in India has been typically influenced by popular discourses, which are characterised by attitudes prevalent in the larger social milieu about the conservatism and ingrained backwardness of the community. The marginal status of Muslim

\footnotetext{
${ }^{1}$ Discourse can be defined as entity, which is composed of sequences, signs and relations among objects, subjects and statements. It is the generation of the concept of the conversation within all modalities and contexts. It signifies the totality of codified language used in a given field of intellectual enquiry and of social practice. Therefore, discursive production means the production and prevalence of a particular knowledge by the dominant groups in society.
} 
women has also been closely associated with stereotypes, entrenched by triple talaq, multiple marriages and purdah. Such stereotypes in both popular and academic domains are further reinforced by the systematic scholarship and information on the unequal access to resources and opportunities experienced by different groups of women in India today. It is also important to highlight that the stereotyped images of the Muslim community colour the understanding about the community and affect even the policies formulated for them. Stereotypes also cause discrimination in the labour market as well as public and private institutions (Shaban, 2012).

\section{Religion and Culture: Constructing Women's Marginality through Knowledge Production}

Muslim community is considered the community of interpretations. Being the minority community adds on a huge responsibility on their part to protect identity and culture, and women's identity is not beyond the monopoly of community. Therefore, women's role and status cannot be comprehended through bypassing the purview of religious and cultural discourses. These are the sites, which have been reproducing and reinforcing their marginality within the community through interpretations of the Quranic verses, which ultimately result in knowledge production. This knowledge production is not at all free from the dynamics of power. The essence of patriarchy and the interests of male-dominated society have always shaped women's rights in society (Engineer, 1999). Women's rights in marriage, divorce, property in Islam have been interpreted by different schools like Hanibal, Malikh from different angles. Asghar Ali Engineer said that Islam is an egalitarian religion but the interpretation of verses has subverted Muslim women's rights (Engineer, 1994).

The art of interpretation is not free from the influence of patriarchal society and culture. Certain verses relating to polygamy, triple talaq, veiling, and wife beating constitute the core of the Muslim personal law and not free from the politics of interpretations. It is important to take a holistic or 'contextual' ap- proach to the analysis of women's question in Muslim society. It is a way of clarifying the meaning of a text by interpreting it historically, and this method revolves around the text, the author and the context (E.McNabb, 2004).

While discussing about the impact of Muslim personal laws on the lives of Muslim women, it can be illustrated by taking up the question of the polygamy and divorce. It has been said that Muslim men can have wives up to four (Engineer, 2013). However, it is important to say that polygamy has been permitted by the Quran in a concrete social context in order to do justice to the weak and it is subjected to the condition that equality of treatment would be ensured. It is very clear from the wordings of the Prophet on polygamy that in order to ensure justice to the orphans, war-widows Muslim men can have four wives (Ahmed, 2011). Another issue, which constitutes the core of Muslim personal law, is divorce or triple talaq. According to a precept of the Prophet, divorce is condemned as the most reprehensible of all things permitted. There is nothing more displeasing to God than divorce. The right to dissolve a marriage is given to the husband as well as to the wife. Women have to observe iddat ${ }^{1}$ for three months to ascertain paternity. The Quran does not permit any outsider to separate a couple who want to live together even if one of them has a physical defect, though this can be a legitimate cause for divorce. The Quran emphasises that divorce should not be a hasty impulsive act but should be finalised only after a period of waiting during which time the couple is counseled and given a chance to rethink on the decision. Talaq is a procedure that can be initiated by the husband alone without the consent of his wife. Besides, the exercise of talaq is extra-judicial and in no way subject to external check. Technically, therefore, the power of the husband to divorce is absolute.

\footnotetext{
${ }^{1}$ Iddat has been defined as the waiting period for a widow or divorced. In Shariat terminology, it is the waiting period for a woman when her nikkah with a man is no more extant for one reason or the other; the waiting period means that after the cessation of nikkah the woman has to restrain herself for another nikkah till the prescribed period is over (Engineer, 1994).
} 
Talaq may be pronounced in a number of ways, e.g., (1) ahsan (2) hasan (3) bid' ah.

The ahsan form of talaq is talaq-i-sunna. The repudiation does not take place at a single sitting nor can it take place during menstruation. Iddat is observed during the period following menstruation that is tuhr or the purity period. Two arbitrators from both sides are appointed to bring about reconciliation. During the iddah period the marriage is not dissolved. If reconciliation takes place, the marriage is saved and no nikkah is needed. In ahsan talaq, even after the third pronouncement of talaq, after the iddah period, the marriage is revocable. The man can remarry his divorced wife. This practice is in accordance with the teaching of the Quran and according to Sunna Rules. Both Sunni and Shia ${ }^{1}$ schools approve of talaq-a-ahsan. The hasan form is talaq-a-sunna but is not as commonly accepted as talaq-a-ahsan. The man is supposed to pronounce talaq during the successive periods of purity or tuhr. A couple can live together as husband and wife if the husband so desires before he pronounces the third talaq. On the third talaq, the marriage is dissolved and the talaq is irrevocable. Therefore, he cannot remarry her. If she wants to remarry, she has to perform halala, that is, marry another man, consummate the marriage, consequently dissolve it, and only then remarry her divorced husband. Prophets and Caliph Ali condemn this process of halala. All Shia and Sunni schools of thought have approved of talaq-a-hasan. Since it is not irrevocable, it is not very popular; yet, the Hanbali Sunni School gives it more im-

\footnotetext{
${ }^{1}$ Sunni and Shia Islam are the two major denominations of Islam. The demographic breakdown between the two denominations is difficult to assess and varies by source, but a good approximation is that greater than $75 \%$ of the world's Muslims are Sunni and $10-20 \%$ are Shia, with most Shias belonging to the twelve traditions and the rest divided between several other groups. Sunnis are a majority in most Muslim communities: in Southeast Asia, China, South Asia, Africa, and some of the Arab world. Shia community constitutes the majority of the citizen population in Iran, Iraq and Bahrain, as well as being a politically significant minority in Lebanon. Pakistan has the largest Sunni and second-largest Shia Muslim population in the world (Engineer, 1994).
}

portance than to other types of talaq. Talaq-abidah is a form of divorce, which is severely criticised since it goes against the rules laid down by the Quran. However, the Sunna approves it. In this form of talaq, the husband unilaterally, without the consent or knowledge of the wife, pronounces talaq. Husband can pronounce talaq once or three times simultaneously, without paying attention to the fact whether wife is in a state of tuhr. The Prophet did clearly not approve of this form of divorce (Baxamusa, 1994).

Apart from this, women's right to inheritance have also been violated in practice. As for property, movable or immovable, generally very few Muslim women work and earn. Islam does not prohibit them from working at all. The Quran allows her to earn. She has the right to own property in her own right. Thus, Islam recognises her individuality and her being as a legal entity. In Islam, there is no concept that she has to confine herself to domestic duties alone. This clearly shows that bringing up children is not her responsibility alone but is a joint one. The husband is equally obliged to arrange for rearing children. However, in traditional society, a man usually expects his wife to confine herself to domestic duties and disapproves of her working in order to earn. It is only in some enlightened families where she is allowed to work. Therefore, the way Islam ensures rights to women and the way it has been interpreted shows huge difference. It is quite clear that the status of women has deteriorated because the legal interpretations have always remained subject to patriarchal influences (Engineer, 1995). Moreover, this art of interpretations has created the core of marginality from within. It is worth mentioning that Muslim women's location in minority community also shapes their experiences. Their minority community identity not only marginalises them within the community but also makes their citizen identity as secondary. Even their access to the government institutions becomes restricted due to their community identity. Therefore, it is not easy to understand their marginality in terms of socioeconomic indicators rather power dynamics 
within the community constructs the marginality question of Muslim women in India.

\section{State and Political Leadership: Constructing Marginality and Muslim as 'Other'}

Revisiting the marginal locations of Muslim women will remain incomplete without reviewing the role of the political leadership and the state to construct the marginality of Muslim women as 'other'. The Indian State has always represented its own claim on Muslim women's marginality. Since independence, the Indian State has tried to protect the identity and culture of the minority groups by not intervening into their private domain, especially in personal laws. This is one of the reasons, which has given rise to the self-legislating Muslim community where religious leaders had played a significant role to define Muslim identity. The application of the law is often a complex matter and the interpretation of the Sharia is the monopoly of Ulemas. Through these principal mechanisms, Ulemas and Mullahs maintain control over Islamic society. Here the purpose is not to blame the State but to understand the puzzle for which women fail to access laws and justice and become marginal. This was visible in the case of 73-year-old Shah Bano (1986). ${ }^{1}$ While all other Indian women may claim the legal right to spousal support after divorce, Muslim women may not. While other women criminally prosecute their husbands for bigamy, Muslim women may not. According to the Sharia Act, a

\footnotetext{
${ }^{1}$ According to Shariat Act (1937), Muslim women cannot demand lifelong maintenance after talaq. It is generally supported on the ground of minority community identity, religion and culture. In 1986, when Shah Bano went to the Supreme Court for demanding her lifelong maintenance, it gave rise to a clash between the collective rights of the community and individual rights and identity. The Supreme Court gave its verdict in favour of Shah Bano. However, Muslim fundamentalists protested this move vehemently on the ground that any change in Shariat Act by the state is against the identity of Muslim community. So the Shah Bano case (1986) shows that women's claim to equal rights is treated as a betrayal to community, the culture and the religion. In addition, the Indian State very consciously institutionalises gender inequality in personal laws on the ground of minority identity and culture (Hasan, 2000).
}

divorced Muslim woman is entitled to a reasonable and fair provision of maintenance within the period of iddat; two years of maintenance for her children; mehr and all the properties given to her by her relatives, friends' husband and husband's relatives. If she does not get it at the time of divorce then she can apply to the Magistrate to direct her husband to follow the order. In response to this, Shah Bano filed a case against her husband and the Supreme Court granted her appeal for lifelong maintenance from her husband.

Nevertheless, this judgment was not a simple one and rather opened the floodgates of debates and discussions on the tricky relationship between gender, community and the state. In response to the Shah Bano case and the subsequent legislation, Muslim community leaders split broadly into two camps. Conservative leaders considered the judgement as an attack to Muslim identity as well as Muslim personal law. Progressive leaders felt that the Supreme Court judgement was in accordance with the basic tenents of Islam and thus it was not an intrusion in Muslim personal law.

Although they did not agree with everything the judgment said, they supported the substantive conclusion: that Muslim man should provide adequate maintenance for destitute, divorced women beyond the period of iddat. Constitutional scholar Granville Austin has argued that conservative opposition was not only imbued with ideological factors but economic and political factors. The judgement, if it stood, threatened not only the sacred text of Islam but economic interests of Muslim men who might otherwise be faced with maintenance payment to ex-wives. Additionally, the political interests of the conservative Muslim leadership were threatened as well. If personal laws were codified, the religious leaders would lose their power to interpret the Quran. To soothe ruffled feelings, the Rajiv Gandhi Government enacted the Muslim Women (Protection of Rights on Divorce) Bill, 1986. This bill explicitly excluded Muslim women from the right to maintenance 
available under the Code of Criminal Procedure $(\mathrm{CrPC})^{1}$ (Hasan, 2000).

The government's response to this judgement was also very crucial as it rests on the need to provide protection of minority identity defined in religious and cultural terms. The government argued that it was against imposing a single pattern on all. It also argued in favour of differentiated criteria of citizenship as against universalistic criteria. It is important to mention that differentiated citizenship is mainly concerned with the inter-group equality, not with intra-group equality. That is why it leaves many structures of discrimination untouched. The government also asserted that the impetus for change must come from within the Muslim community. Therefore, the government championed community rights, which gives priority to community's self-defining and selfdetermining character (Jayal, 2002).

Indian state very deliberately never intervened in the private sphere of minority community. It is not only because of preserving their culture and identity but also for maintaining its own vote bank. It was quite clear in Shah Bano case (1986). The state could not guarantee the right to maintenance after divorce because the Muslim fundamentalists perceived it as an intrusion into their culture and religion. Muslim religious leaders and ulemas issued a fatwa (proclamation) that guaranteeing maintenance right was against the teachings of Islam. Within few months, the whole issue took the form of communal agitation claiming that Islam was in danger. Modern Indian State intervened in the religion of the majority community through Hindu Code Bill ${ }^{2}$ but it has never intervened in

\footnotetext{
${ }^{1}$ The Code of Criminal Procedure is the main legislation on procedure for administration of substantive criminal law in India. It was enacted in 1973 and came into force on 1 April 1974. It provides the machinery for the investigation of crime, apprehension of suspected criminals, collection of evidence, determination of guilt or innocence of the accused person and the determination of punishment of the guilty. Additionally, it also deals with public nuisance, prevention of offences and maintenance of wife, child(ren) and parents (Hasan, 2000).

${ }^{2}$ Following India's independence in 1947, the postcolonial government led by Prime Minister Jawaharlal Nehru completed the codification and reform of Hindu personal
}

the religion of minority. There are two problems behind this issue. First, the Indian interpretation of secularism based on which Indian State devised policies premises on a 'principled distance' between the government and religion. Second is the conflict between the claims of cultural communities and women's rights of equal citizenship. The State never tried to reform Muslim personal law for guaranteeing citizenship rights to all communities but the political leadership realised that respecting religious sensibilities was more important.

In postcolonial India, the role of the state to create minority identity is unavoidable. The State did this not only by maintaining a 'principled distance' from minorities but also by refusing to intervene in the domain of personal law. The modern state has become the institution through which personal laws have to be negotiated and gender has become the site on which they were negotiated. In the 1980s, the State had an important role in cementing a particular perception of the Muslim community as inherently conservative, resistant to reform and oppressive of women's rights by accepting the conservative position on this issue. The progressive interpretation would have granted greater rights of maintenance to Indian Muslim women within the framework of Islam. In this case, the role of the State was critical in sanctioning one set of views as representing the view of all, even the most Indian Muslims. In addition, far from protecting and enabling the

law, a process started by the British. According to the British policy of non-interference, reform of personal law should have arisen from a demand from the Hindu community. This was not the case, as there was significant opposition from various Hindu politicians, organisations and devotees who saw themselves unjustly singled out as the sole religious community whose laws were to be reformed. However, the Nehru administration saw such codification as necessary in order to unify the Hindu community, which ideally would be a first step towards unifying the nation. They succeeded in passing four Hindu code bills in 1955-56: the Hindu Marriage Act, Hindu Succession Act, Hindu Minority and Guardianship Act, and Hindu Adoptions and Maintenance Act. These continue to be controversial to the present day among women's organisations, religious, and nationalist groups (Hasan, 2000). 
dissident, vulnerable voices within the Muslim community, the state sanctioned and authorised the voices of and an androcentric interpretation of the Muslim personal law of maintenance. Instead of responding to the socioeconomic marginality of Muslim community, the state has constructed its own version of marginality for Muslim women.

Not only the state, but also the role of women's movement towards Muslim women's issues like triple talaq, polygamy as well as burqa has remained crucial in post-independence India. If the 1970s and 1980s were an age of exploration, the 1990s was an age of doubt and reflection. The political polarisation over MandalMasjid unsettled the discursive context within which questions of women's rights and gender equality had been formulated. The evidence of upper-caste and middle-class women's opposition to affirmative action for disadvantaged castes came as evidence of the caste-class figures among women and was a challenge to the political possibilities of a singular feminist gender-speak (Banerjee et al., 2011). After 1980s, the question of Muslim women's identity and difference became very significant with the Shah Bano case. This is the case, which ultimately resulted in the victory of Muslim personal law, and made the connection between women and religious personal laws very significant. In fact, this case further escalated one of the major demands by women's movement, that is, Uniform Civil Code to replace the religion-based personal laws, which govern issues of family, that is, marriage, divorce, property inheritance custody and guardianship of children. The judgment was widely criticised by feminists, liberals as well as secularists on the simple ground that it violates women's rights. Where Muslim religious leader found the judgment as an intrusion into their community as well as an attack to their identity, Muslim liberals, feminists and social reformers began campaigns all over India. They were in favour of upholding of section $125^{1}$ and demanded im-

1 Under section $125 \mathrm{CrPC}$, every woman can claim to maintenance and it applies to all religions, castes and creeds. Maintenance can also be claimed under the respective personal laws of people following different provements in the legal rights of Muslim women against polygamy and to maintenance. During this time, the autonomous women's groups came together to organise a demonstration, demanding that a uniform civil code must be framed.

\section{Conclusion}

The essay in conclusion highlights that the state of marginality is not only embedded in socioeconomic conditions but also in their representation of identities in several discourses and bodies of knowledge. It can be generated either by the state institutions or by the religious authority of the community, which ultimately results in producing discourses on marginality of Muslim women. The dominant instrument of alienating Muslims from mainstream Indian society and the majority community is through the construction of the 'other'. This politics behind the representation of 'other' constructs their identity, which ultimately affects the 'equity' issues. The discrimination in and exclusion from government-run welfare programmes for employment and political representation, in effect, has led to the collective alienation and deprivation of the community. This, at the end of the day, influences the status of Muslim women at socio-economic level as well as at various sites including discourses and bodies of knowledge. Therefore, it is important to mention Muslim women's marginality is not only socio-economic but also discursive and it cannot be understood without the comprehending the politics of intersections of gender, religion, class and community in India. Therefore, structures as well as discourses shape Muslim women's experiences of marginality in our society.

faiths and proceedings under such personal laws are civil in nature. The issue of maintenance became debatable in Shah Bano case (1986) in which the Supreme Court tried to uphold section 125 but the government could not materialise verdict of the court due to vociferous opposition from the minority community. 


\section{About the Author}

Esita Sur teaches Political Science at the Scottish Church College, Kolkata. She obtained her MPhil in Development Studies from Institute of Development Studies in Kolkata. She is now pursuing Ph.D in Muslim Women's Activism in Kolkata and Mumbai. She has a number of publications: the latest one is 'Politics of Muslim Women's Agency: A Story of Muffled Voices', published in the International Journal of Anthropology, Man in India in 2012.

\section{References}

Ahmed, L. (2011). Women in Islam. New Delhi: A.P.H Publising House

Baxamusa, R. (1994). Need for change in the Muslim Personal Law: Relating to divorce in India. In A. A. Engineer (ed.), Problems of Muslim Women in India, Hyderabad: Orient Longman, 19-25

Banerjee, N, Sen, Samita and Dhawan (2011). Mapping the Field: Gender Relation in Contemporary India. Kolkata: Stree Publications

E.McNabb, D. (2004). Research Methods for Political Science Quantitative and Qualitative Methods. New Delhi: PHI Learning Private Limited

Engineer, A. A. (1994). Problems of Muslim women in India-Introduction. In A. A. Engineer (ed.), Problems of Muslim Women in India.Hyderabad: Orient Longman, xii-xiii

Engineer, A. A. (1995). The Quran, Women and the Modern Society. New Delhi: Sterling Publishing

Hasan, Z. (2000). Politics and the State in India. New Delhi: Oxford University Press
Howarth, D. (2002). Discourse. New Delhi: Viva Books Private Limited

Jayal, N. G. (2002). Democracy and the State. New Delhi: Oxford University Press

M.Lovell, A. (2004). Marginality. In D. Levinson (ed.), Encyclopedia of Homelessness. United Kingdom: Birkshire Publishing Group

Menon, H. Z. (2004). Unequal Citizens: A Study of Muslim Women in India. New Delhi: Oxford University Press

Sachar, R. K. (2006). Social, Economic and Educational Status of Muslim Community in India. New Delhi: Akalank Publications

Sarkar, M. (2008). Visible Histories, Disappearing Women: Producing Muslim Womanhood in Late Colonial Bengal. New Delhi: Kali for Women

Shaban, A. (2012). Introduction. In A. Shaban (ed.), Lives of Muslims in India. NewDelhi: Routledge, 17-20

Sur, E. (2013). Politics of inclusion and exclusion of Muslim women in India. Women's Link, 3136

Williams, R. V. (2012). Making minority identities: Gender, state, and Muslim personal law. In R. Robinson (ed.), Minority Studies. New Delhi: Oxford University Press, 73-77

\section{Acknowledgements}

This is to acknowledge that I am grateful to the anonymous reviewers of my article. Their insightful comments have enabled me to learn many things about the academic writing. 